\title{
A College Library Reports on Its Freshman Lecture Program
}

F OR THE PAST FIFTEEN YEARS all freshmen taking English 1 at Brooklyn College have had one of their class periods in composition devoted to a lecture on bibliographic procedure, given in the library by librarians. Since the library, now arranged by form, is to reorganize on a subject division basis this year when its extension is completed, and will then reconsider its orientation program, this appears to be a good time for stock-taking on current practice.

First, a word about our institution and students. Brooklyn College is a liberal arts college, municipally supported, with a full-time day session student body of approximately eight thousand and a similar number in the School of General Studies. Approximately two thousand of the latter are matriculated for the baccalaureate degree. The students are, for the most part, the product of the city's high schools, and must have received an 84 per cent high school average to be eligible for admission. In addition to being selected, bright, students, most of them come to the college with some background in the use of a library, since one of the questions on the English "Regents" examination (required in all New York State secondary schools) deals with this subject, and they are therefore given instruction along these lines.

Our library orientation program con-

Mrs. Sellers is Associate Librarian and Miss Ciolli is a member of the Reference Department at Brooklyn College. sists of two parts-a tour and a lecture. The former is under the supervision of the director of admissions and takes place during Freshman Orientation Week. The entering freshmen tour the campus under the guidance of upper classmen and visit the library in the course of their rounds. The supervisor of the library's freshman lecture program briefs the student guides and provides them with outlines.

The lecture, which is, as indicated, a one-period activity, ${ }^{1}$ aims to accomplish two purposes: acquaint the students with the physical organization of the library, particularly those aspects which are peculiar to Brooklyn College (e.g., the divided catalog, arrangement of materials by form, separate housing of bound and current periodicals); and drill them in the fundamental procedures to be followed in searching for data for a term paper.

The following points are covered:

I. Brief statistics about the collection and introduction to library organization

II. The Catalog
A. Author-Title Section
1. Kinds of authorship
2. Title as secondary entry
3. Title as main entry
B. Subject Section
1. Person as subject
2. Subdivisions

1 A period in the School of General Studies lasts seventy-five minutes instead of the usual fifty. Since the evening student is less apt to use the library than his day counterpart, the extra time is used for a brief tour of the stacks and reference room. 
C. Unit Card System

D. Cross References

III. Bibliographies and Indexes

IV. Reference Books

V. Sample bibliography

VI. Helps for the student

A. Reference advisory service

B. Brooklyn College handbooks and bibliographies

The lecture is illustrated with slides made to our specifications. Included among them are floor plan sketches, catalog cards, and pages from various reference tools. Questions are permitted as each item is covered and again at the end of the lecture. A copy of the library's student handbook ${ }^{2}$ is distributed to each student after the lecture for review purposes. The follow-up, formerly a problem sheet worked out in the library, was changed to an examination after it became clear that the former had become a "co-operative effort."

The examination, a short-answer type, ${ }^{3}$ given approximately one week after the lecture to give the students an opportunity to prepare for it, is composed by the library's reference division and revised each year. It seeks to discover whether the students can identify the items on a standard author catalog card and the items in a typical Readers' Guide to Periodical Literature entry; can comprehend the general purpose of such reference tools as the Cambridge Bibliography of English Literature, the Dictionary of American Biography, the Dictionary of National Biography, the Education Index, the Essay and General Literature Index, the Harvard Guide to American History, Murray's New English Dictionary, the New York Times Index, and Who's Who in America; and, finally, whether they are familiar with

\footnotetext{
2"Clue to the Resources and Services of Brooklyn College Library, 1957."

3Sample copies of these tests may be obtained from the authors.
}

the physical organization of the library and its rules and procedures.

In the seven semesters between the fall of 1954 and the fall of 1957, 520 English sections heard the lecture and took the test. Of these, 4,276 papers from 189 sections of English were analyzed, and a tabulation made of the questions which yielded the largest number of incorrect responses. Consistently the item posing the greatest difficulty was periodical material-how to look up subjects in the indexes and in the catalog, how to locate specific issues, how to distinguish between current and bound volumes-in fact, every aspect but interpretation of the entry in the index. The latter is apparently one of the items that has been drilled to the point of recall in the high school library lessons.

The second most troublesome area was found to be reference tools. The students fell down on such questions as which reference book among a choice would best supply information on Raleigh, Swift, and Caxton, the importance and location of the index volume of the $E n$ cyclopaedia Britannica, the period covered by Poole's Index to Periodical Literature, etc.

The catalog was the third obstacle. The fact that ours is divided into author-title and subject sections takes some time to sink in, but in addition the freshmen had trouble with the filing system, the author as subject (they indicated that they would look in the author-title catalog for books about Con$\mathrm{rad}$ ), and the listing of main entry cards for periodicals. Fourth among the stumbling blocks were location questionswhere the New York Times is kept, what floor the pamphlet file is on, where to charge books and periodicals taken from the stacks.

Aside from the entire area of periodical materials, then, it appears that the questions presenting the most difficulty are either tools new to the beginning 
college student (e.g., the Education Index, Poole's Index to Periodical Literature, the Dictionary of National Biography, and the Dictionary of American Biography), or elements of service and organization peculiar to Brooklyn College.

As far as the four difficult areas are concerned, the fourth group does not give us any concern because it is simply a question of time before the students know their way about. The other three problem areas are taken care of through the individual help available at all desks where librarians are on duty. At the reference desk, in addition, special advisory service for students working on term papers is provided.

On the cheerful side, it is plain that little difficulty is experienced by the students in such areas as: interpreting the items on catalog card and in a typical Readers' Guide to Periodical Literature entry; comprehending the general purpose of such simple reference tools as Who's Who, the New English Dictionary, the New York Times Index; knowing where in the library to find teaching aids, government publications, and reserve books.

Do we feel the lecture is helpful? We emphatically do. Thanks to the fact that several of the lecturers work at public service desks (reference, education, periodicals and documents, and circulation) we are in a strategic position to judge the results. It is very easy to tell a freshman who has not had the lecture from one who has had that benefit. The latter will, if he doesn't know anything else, know how to phrase his questiona skill that appears to be lacking before the fifty-minute exposure to lecture and slides.

That the faculty members are in agreement with us about the program was proved when a Ford Foundation grant made available a study of the English courses in the new curriculum.
We had switched the lecture from the first term to the second, but the seminar studying the course offerings considered that the objectives of the elementary course would be better served if the students received the lecture in the first term rather than the second. To quote from the report: "The students themselves have voiced the feeling that they need the guidance provided by the library lecture much sooner than the spring of their freshman year. We all find the library lectures especially valuable, and want them as close to the beginning of the year's work as is feasible."

Furthermore, requests for the lecture have also come from instructors in vocational studies programs, whose students, since they are not enrolled in the same freshman English courses as those offered students matriculated for a baccalaureate degree, are not ordinarily scheduled to receive a lecture.

Though we feel confident that we are on the right path, we do not feel satisfied with the program as it is at present. We know that fifty minutes is insufficient for adequate coverage of all the necessary information and skills. Unfortunately, we cannot afford to give more time with the present staff. Ours is a small one (twenty-five professionals, two of whom are Fellows) for the number of students and the type of service given. In order for the lectures to reach the ninety-five sections of freshman English without overburdening any one person, ten librarians participate in the program. All the departments (including acquisition and catalog) are represented among the ten, and even now the time devoted to this project (lecturing, briefing meetings) is sometimes a burden to the departments. A second hour cannot, therefore, even be considered now.

We hope, however, that the library extension will mean more librarians, which in turn will mean more hours for lectures. 